\title{
KERAGAMAN MORFOLOGI DAN RESPON PERLAKUAN PRA PERKECAMBAHAN BENIH DARI LIMA POPULASI SAWO KECIK (Manilkara kauki (L.) Dubard)
}

\author{
Variation of Seed Morphology and Germination Pre Treatment Response from \\ Five Populations of Sawo Kecik (Manilkara kauki (L.) Dubard) \\ Dede J. Sudrajat dan/and Megawati \\ Balai Penelitian Teknogi Perbenihan Bogor \\ Jl. Pakuan Ciheulet PO. BOX 105 Bogor, 16001 Telp./Fax (0251) 8327768 \\ Naskah masuk : 6 Oktober 2009 ; Naskah diterima : 5 Maret 2010
}

\begin{abstract}
Variation in seed morphology and germination pretreatment response of five genotypes of sawo kecik (Manilkara kauki (L.) Dubard) was evaluated in the population level. The aim of the research was to identify morphology variations, the effect of pre treatment on seed germination, and correlation between annual precipitation and elevation and seed morphology and germination. The seed were examined for variations in seed length, sed width, seed weight, seed thickness, seed coat thickness, and germination. Germination test used six pretreatments, i.e. control, soaking in the water for 3 days, soaking in the hot water and cooling for 24 hours, drying-soaking for 3 days (A4), soaking in $\mathrm{H}_{2} \mathrm{SO}_{4} 2 \mathrm{Nfor} 2$ hours (A5), and soaking in $\mathrm{KNO}_{3} 0.2 \%$ for 24 hours (A6). The correlation between annual precipitation and elevation with seed morphology and germination was calculated by Person's correlation coefficient. The result showed that the Kaliurang and Benoa seed lots showed higher seed length and weight. However Kaliurang seed lot provided higher seed size because the seed width is highest. The elevation positively correlated with seed width and weight $(r=0.877, p=0.05$ and $r=0.807, p=0.05)$. The seed pre treatment signifincantly affected the capacity and speed of germination. Drying-soaking treatment resulted the better capacity and speed of germination on all seedlots. Alas Purwo seed lot showed the lowest capacity and speed of germination due to thickest seed coat. The seed coat thickness negatively correlated with germination capacity and speed ( $r=-0.856, p=0.05, r=-0.829, p=0.05)$, while the mean annual precipitation of seed collection sites showed significant correlation with germination speed $(r=0.802$, $p=0.05)$.
\end{abstract}

Keywords :germination, Manilkara kauki, morphology, pre treatment

\begin{abstract}
ABSTRAK
Variasi morfologi dan perkecambahan benih sawo kecik (Manilkara kauki (L.) Dubard) dievaluasi pada tingkat populasi. Tujuan penelitian ini adalah mengetahui variasi morfologi antar kelompok benih dari 5 populasi, pengaruh perlakuan pra perkecambahan terhadap perkecambahan beberapa kelompok benih, dan hubungan antara variabel iklim (curah hujan dan ketinggian tempat) dengan morfologi dan perkecambahan benih. Benih dikumpulkan dari 5 populasi, yaitu Lembar, Mokmer, Benoa, Alas Purwo, dan Kaliurang. Kelompok-kelompok benih tersebut dievaluasi keragaman panjang, lebar, tebal, tebal kulit, berat benih, dan perkecambahannya di rumah kaca. Untuk perkecambahan benih, masing-masing kelompok benih diberi 6 perlakuan pendahuluan, yaitu kontrol (A1), perendaman dalam air selama 3 hari (A2), perendaman dalam air panas dan dibiarkan dingin selama 24 jam (A3), rendam-jemur selama 3 hari (A4), perendaman dalam $\mathrm{H}_{2} \mathrm{SO}_{4} 2 \mathrm{~N}$ selama 2 jam (A5), dan perendaman dalam $\mathrm{KNO}_{3} 2 \%$ selama 24 jam (A6). Korelasi antar parameter curah hujan dan ketinggian tempat dengan morfologi benih (panjang, lebar, tebal benih, dan tebal kulit) dan perkecambahan (daya dan kecepatan berkecambah) benih dianalisis
\end{abstract}


dengan koefisien korelasi Pearson. Hasil penelitian menunjukkan bahwa kelompok benih Kaliurang dan Benoa mempunyai panjang dan berat benih yang lebih tinggi, namun kelompok benih Kaliurang mempunyai ukuran yang lebih besar jika dilihat dari lebar benih. Ketinggian tempat tumbuh berkorelasi positif dengan berat dan lebar benih $(r=0,877, p=0,05$ dan $r=0,807, p=0,05)$. Perlakuan pendahuluan sangat berpengaruh nyata terhadap kelompok benih Mokmer, Alas Purwo, Kaliurang, dan Benoa, sedangkan untuk kelompok benih Lembar, perlakuan pendahuluan tidak berpengaruh nyata terhadap daya berkecambahnya. Perlakuan A3 mempunyai kecenderungan menghasilkan daya dan kecepatan berkecambah relatif lebih baik pada semua kelompok benih. Kelompok benih Alas Purwo mempunyai daya dan kecepatan berkecambah paling rendah yang disebabkan oleh kulit benih paling tebal. Tebal kulit benih berkorelasi negatif dengan daya dan kecepatan berkecambah $(r=-0,856, p=0,05, r=-0,829$, $\mathrm{p}=0,05)$, sedangkan curah hujan berkorelasi dengan kecepatan berkecambah benih $(\mathrm{r}=0,802, \mathrm{p}=0,05)$.

\section{Kata kunci : Manilkara kauki, morfologi, perkecambahan, perlakuan pendahuluan}

\section{PENDAHULUAN}

Sawo kecik (Manilkara kauki (L.) Dubard) merupakan salah satu jenis tanaman potensial yang bernilai ekonomi tinggi. Kayunya dapat digunakan untuk bahan konstruksi, furnitur dan kerajinan patung. Selain itu, jenis ini juga mempunyai arsitektur yang baik sehingga banyak ditanam sebagai pohon peneduh di kawasan perkotaan. Di Indonesia, sawo kecik tumbuh secara alami di beberapa kawasan seperti di Jawa (pesisir Selatan Banyuwangi, pesisir Jakarta, dan Pulau Karimun Jawa), Bali, Sulawesi, Kagean, Pulau Weh dan terdapat juga di Nusa Tenggara. Jenis ini tumbuh hingga ketinggian $300 \mathrm{~m}$ dpl (Alrasyid, 1971).

Sebaran tumbuh yang cukup luas memungkinkan adanya variasi sebagai akibat perbedaan genetik dan lingkungannya. Perbedaan tersebut diduga akan terjadi juga pada tingkat benih. Secara fisik, antar kelompok benih dari tempat tumbuh berbeda memungkinkan terjadinya perbedaan karena variasi berat dan ukuran benih dipengaruhi oleh faktor keturunan, lingkungan dan faktor pertumbuhan (Bonner, 1987). Beberapa penelitian menunjukkan adanya variasi sifat morfologi benih antar populasi seperti pada Celtis australis di Himalaya Tengah, India (Singh et al., 2006), Trigonobalanus doichangensis di Cina Selatan, dan Styrax benzoin di Tapanuli Utara (Jayusman, 2006). Variasi antar kelompok benih yang berasal dari sumber berbeda juga terjadi pada karakteristik perkecambahan benihnya seperti pada jenis kemiri (Aleurites moluccana) (Kusumawardhani, 1997), Abies guatemalensis
(Andersen, 2008), dan Juniperus procera (Mamo et al., 2006) sehingga efektivitas suatu perlakuan perkecambahan dapat saja berbeda antar kelompok benih dari berbagai populasi.

Penelitian ini bertujuan untuk mengetahui variasi morfologi antar kelompok benih (populasi), pengaruh perlakuan pra perkecambahan terhadap perkecambahan beberapa kelompok benih, dan hubungan antara faktor geoklimat dengan morfologi dan perkecambahan benih. Informasi variasi fisik akan berguna dalam mempertimbangkan metode seleksi dan sortasi benih berdasarkan ukuran/berat benih dan juga mengetahui variasi morfologi antar kelompok benih sebagai informasi awal untuk kegiatan konservasi genetik. Variasi respon kelompok benih terhadap perlakuan pendahuluan dapat digunakan untuk mengetahui tingkat dormansi benih dalam hubungannya dengan kondisi lingkungan tanaman induk sehingga diperoleh metode perkecambahan terbaik untuk setiap kelompok benih. .

\section{BAHAN DAN METODE}

Pengunduhan buah sawo kecik dilakukan di Benoa (Bali), Mokmer (Bali), Lembar (Lombok), Pantai Plengkung-Alas Purwo (Banyuwangi), dan Kaliurang (Yogyakarta) (Tabel 1). Untuk setiap lokasi dipilih 25 pohon induk dan diunduh buahnya sehingga dapat mewakili keragaman populasi tersebut. Pengunduhan dilakukan terhadap buah yang telah masak secara fisiologis yang dicirikan dengan warna buah kuning kemerahan dengan 
daging buah yang lunak. Pengujian benih dilakukan di Laboratorium dan Rumah Kaca Balai Penelitian Teknologi Perbenihan Bogor.

Bahan yang digunakan dalam penelitian ini adalah media pasir dan tanah, $\mathrm{H}_{2} \mathrm{SO}_{4}, \mathrm{KNO}_{3}$, bak kecambah, plastik transparan, dan lain-lain. Alat yang digunakan meliputi GPS, kaliper digital, timbangan analitik, gelas piala, plastik transparan, dan lain-lain.

Tabel (Table) 1. Gambaran lokasi pengumpulan benih (Description of the locations of seed collection)

\begin{tabular}{|c|c|c|c|c|}
\hline $\begin{array}{c}\text { Populasi } \\
\text { (Populations) }\end{array}$ & $\begin{array}{c}\text { Letak geografis } \\
\text { (Geographical positions) }\end{array}$ & $\begin{array}{c}\text { Ketinggian } \\
\text { tempat } \\
\text { (Elevation) } \\
(\mathrm{m} \mathrm{dpl})\end{array}$ & $\begin{array}{l}\text { Curah hujan } \\
\text { (Annual } \\
\text { precipitation) } \\
\text { (mm/tahun) }\end{array}$ & $\begin{array}{c}\text { Waktu } \\
\text { pengunduhan } \\
\text { (Time of } \\
\text { collections) }\end{array}$ \\
\hline Benoa & $8^{\circ} 47^{\prime} 01,11^{\prime \prime} \mathrm{LS} ; 115^{\circ} 13^{\prime} 44,25^{\prime \prime} \mathrm{BT}$ & 2 & 1.800 & April \\
\hline Mokmer & $8^{\circ} 44^{\prime} 39,75^{\prime \prime} \mathrm{LS} ; 115^{\circ} 09^{\prime} 46,83^{\prime \prime} \mathrm{BT}$ & 3 & 2273 & Mei \\
\hline Lembar & $8^{\circ} 43^{\prime} 46,98^{\prime \prime} \mathrm{LS} ; 116^{\circ} 04^{\prime} 22,84^{\prime \prime} \mathrm{BT}$ & 5 & 1409 & Juni \\
\hline Kaliurang & $7^{\circ} 41^{\prime} 14,20^{\prime \prime} \mathrm{LS} ; 110^{\circ} 24$ '49.10"BT & 332 & 4.488 & Juli \\
\hline Alas Purwo & $8^{\circ} 43^{\prime} 25,48^{\prime \prime} \mathrm{LS} ; 114^{\circ} 21^{\prime} 44,67^{\prime \prime} \mathrm{BT}$ & 1 & 1.500 & Juli \\
\hline
\end{tabular}

Ekstraksi benih dilakukan secara basah dengan memeram benih selama 2-3 hari dan kemudian mengelupaskan daging buahnya secara manual dengan bantuan air. Sebelum pengujian, benih dikeringanginkan selama 3 hari pada suhu kamar hingga kadar airnya mencapai rata-rata $17-20 \%$.

Pengukuran morfologi (panjang, lebar, tebal kulit, dan berat) benih menggunakan kalliper digital dengan 4 ulangan contoh uji sebanyak 100 butir benih yang diambil secara acak dari suatu kelompok benih. Panjang, lebar, tebal kulit, dan berat benih disajikan dalam bentuk $\pm \alpha$.se (rata-rata \pm standar error).

Analisis ragam digunakan untuk menguji pengaruh kelompok benih terhadap parameter morfologi benih. Uji lanjut Duncan digunakan untuk menguji perbedaan fisik antar kelompok benih. Selain itu dilakukan juga uji korelasi antar parameter fisik benih dengan daya dan kecepatan berkecambahnya.

Pengujian pengaruh perlakuan pendahuluan terhadap perkecambahan benih dilakukan dengan rancangan acak lengkap terhadap setiap kelompok benih secara terpisah. Hal ini dilakukan selain untuk mendapatkan teknik perkecambahan terbaik untuk setiap kelompok benih juga kemungkinan dikembangkannya standar metode uji perkecambahan benih yang dapat diterapkan untuk setiap kelompok benih. Perlakuan yang digunakan adalah : kontrol (A0), direndam air dingin selama $3 \times 24$ jam (A1), direndam air panas dan dibiarkan dingin selama 24 jam (A2), direndam-jemur $3 \times 24$ jam (A3), direndam $\mathrm{H}_{2} \mathrm{SO}_{4} 2 \mathrm{~N}$ selama 30 menit (A4), dan direndam $\mathrm{KNO}_{3} \quad 0,2 \%$ selama 24 jam (A 5). Pengecambahan dilakukan pada media pasir dalam bak kecambah yang ditutup plastik transparan selama 2 minggu pertama (Sudrajat, 2008). Analisis ragam menggunakan model rancangan acak lengkap pada data yang ditransformasi dengan arcsin. Apabila perlakuan berpengaruh nyata terhadap parameter yang diamati, pengujian dilanjutkan dengan uji jarak Duncan (Steel dan Torrie, 1980).

\section{HASIL DAN PEMBAHASAN}

\section{A. Karakteristik Morfologi Benih}

Kelompok benih dari 5 populasi sawo kecik berpengaruh sangat nyata terhadap panjang, lebar, tebal, tebal kulit, dan berat benih (Lampiran 1). Tabel 2 memperlihatkan adanya perbedaan morfologi (panjang, lebar, tebal, tebal kulit benih, dan berat benih per butir) yang nyata antar kelompok benih. Untuk tebal, perbedaan tidak terlalu bervariasi karena hanya melibatkan notasi a dan $b$, sedangkan berat benih per butir lebih bervariasi karena hampir semua kelompok benih menunjukkan berbedaan yang lebih luas yang melibatkan notasi a, b, c, dand.

Kelompok benih Kaliurang dan Benoa mempunyai panjang dan berat benih yang lebih tinggi. Kelompok benih Kaliurang dilihat dari 
lebarnya juga mempunyai ukuran yang lebih besar. Untuk tebal kulit benih, kelompok benih
Alas Purwo mempunyai kulit yang paling tebal berbeda di antara kelompok benih yang lainnya.

Tabel(Table) 2. Perbedaan karakteristik benih dari lima kelompok benih sawo kecik (Differentiation of seed traits from 5 seed lots of sawo kecik)

\begin{tabular}{|l|c|c|l|l|l|}
\hline \multicolumn{1}{|c|}{$\begin{array}{c}\text { Populasi } \\
\text { (Populations })\end{array}$} & $\begin{array}{c}\text { Panjang benih } \\
(\text { Seed length }) \\
(\mathrm{cm})\end{array}$ & $\begin{array}{c}\text { Lebar benih } \\
(\text { Seed width }) \\
(\mathrm{cm})\end{array}$ & $\begin{array}{c}\text { Tebal benih } \\
(\text { Seed thickess }) \\
(\mathrm{cm})\end{array}$ & $\begin{array}{c}\text { Tebal kulit } \\
\text { (Seed coat } \\
\text { thickness })(\mathrm{mm})\end{array}$ & $\begin{array}{c}\text { Berat per butir } \\
\text { (Seed weight }) \\
(\mathrm{g})\end{array}$ \\
\hline Benoa & $1,990 \pm 0,021 \mathrm{a}$ & $1,045 \pm 0,023 \mathrm{bc}$ & $0,757 \pm 0,012 \mathrm{c}$ & $0,133 \pm 0,005 \mathrm{~b}$ & $0.747 \pm 0.013 \mathrm{~b}$ \\
Mokmer & $1,835 \pm 0,020 \mathrm{bc}$ & $1,022 \pm 0,031 \mathrm{c}$ & $0,766 \pm 0,014 \mathrm{c}$ & $0,140 \pm 0,005 \mathrm{~b}$ & $0,651 \pm 0,028 \mathrm{~d}$ \\
Lembar & $1,863 \pm 0,037 \mathrm{~b}$ & $1,068 \pm 0,029 \mathrm{ab}$ & $0,771 \pm 0,014 \mathrm{bc}$ & $0,142 \pm 0,005 \mathrm{~b}$ & $0,711 \pm 0,019 \mathrm{c}$ \\
Kaliurang & $1,894 \pm 0,032 \mathrm{a}$ & $1,092 \pm 0,007 \mathrm{a}$ & $0,792 \pm 0,006 \mathrm{a}$ & $0,131 \pm 0,005 \mathrm{~b}$ & $0,884 \pm 0,031 \mathrm{a}$ \\
Alas Purwo & $1,810 \pm 0,017 \mathrm{c}$ & $1,037 \pm 0,015 \mathrm{bc}$ & $0,789 \pm 0,007 \mathrm{ab}$ & $0,161 \pm 0,004 \mathrm{a}$ & $0,687 \pm 0,017 \mathrm{c}$ \\
\hline
\end{tabular}

Keterangan(Notes): Angka rata-rata dalam kolom sama yang diikuti oleh huruf sama menunjukkan bahwa nilai rata-rata tidak berbeda nyata pada tingkat kepercayaan 95\% uji Duncan (Means within a column followed by the same letters showed that mean are not significantly different at $95 \%$ confident level of Duncan's multiple range test)

Perbedaan ukuran ini kemungkinan ada hubungannya dengan ketersediaan air sewaktu proses perkembangan buah. Kelompok benih Benoa diunduh pada bulan April pada saat masih turun hujan sehingga perkembangan buah hingga proses pematangan terjadi pada musim hujan sehingga buah yang terbentuk pun relatif lebih besar jika dibandingkan dengan kelompok benih
Mokmer (diunduh pada bulan Mei) yang secara geografis jaraknya cukup dekat. Untuk kelompok benih Kaliurang, ukuran benihnya lebih besar dan berat yang diduga karena perbedaan karakteristik lingkungan pohon induk yang cukup besar (ketinggian tempat dan curah hujan) dengan lingkungan asal kelompok benih lainnya.

Tabel(Table)3. Koefisien korelasi Pearson antara curah hujan dan ketinggian tempat lokasi pengumpulan dengan karakter kelompok benih sawo kecik (Pearson's correlation coefficients between annual precipitation and elevation of location of seed collection with traits of sawo kecik seed lots)

\begin{tabular}{|l|c|c|c|c|c|}
\hline \multirow{2}{*}{$\begin{array}{c}\text { Variabel geoklimat } \\
\text { (Geoclimate variables) }\end{array}$} & \multicolumn{5}{|c|}{ Karakter benih (Seed traits) } \\
\cline { 2 - 6 } & $\mathrm{BB}$ & $\mathrm{PB}$ & $\mathrm{LB}$ & $\mathrm{TB}$ & $\mathrm{TKB}$ \\
\hline $\begin{array}{l}\text { Curah hujan tahunan (Annual } \\
\text { precipitation) }\end{array}$ & $0,507^{\mathrm{ns}}$ & $0,199^{\mathrm{ns}}$ & $0,256^{\mathrm{ns}}$ & $-0,170^{\mathrm{ns}}$ & $-0.659^{\mathrm{ns}}$ \\
\hline Ketinggian tempat (Elevation) & $0,877^{*}$ & $-0,011^{\mathrm{ns}}$ & $0,807^{*}$ & $0,628^{\mathrm{ns}}$ & $-0,004^{\mathrm{ns}}$ \\
\hline
\end{tabular}

Keterangan (Notes): $\mathrm{BB}=$ berat benih (seed weight), $\mathrm{PB}=$ panjang benih (seed length), $\mathrm{LB}=$ lebar benih (seed width), $\mathrm{TB}=\mathrm{tebal}$ benih (seed thickness), TKB=tebal kulit benih (seed coat thickness).

* = Berpengaruh nyata pada tingkat kepercayaan 95\% (Significant at $95 \%$ confident level) $\mathrm{ns}=$ Tidak berpengaruh nyata $($ Not significant $)$

Ketinggian tempat berkorelasi positif nyata dengan berat dan lebar benih dengan koefisien korelasi 0,877 dan 0,807 (Tabel 3). Makin tinggi tempat tumbuh menghasilkan benih yang makin berat dan makin lebar (Gambar 1), namun untuk karakter morfologi lainnya (panjang, tebal, dan tebal kulit benih) tidak menunjukkan adanya korelasi yang kuat dengan faktor lingkungan (curah hujan dan ketinggian tempat). Beberapa penelitian melaporkan berat benih meningkat dengan meningkatnya ketinggian tempat, yaitu pada Cordia africana (Loha et al., 2006), Sorghum bicolor (Ayana dan Bekele, 2000), dan Pinus halepensis (Boulli et al., 2001), namun pada beberapa jenis juga tidak menunjukkan korelasi yang signifikan seperti pada Betula pendula (Holm, 1994), Ranunculus acris (Totland dan Birks, 1996), dan Carex flacca 


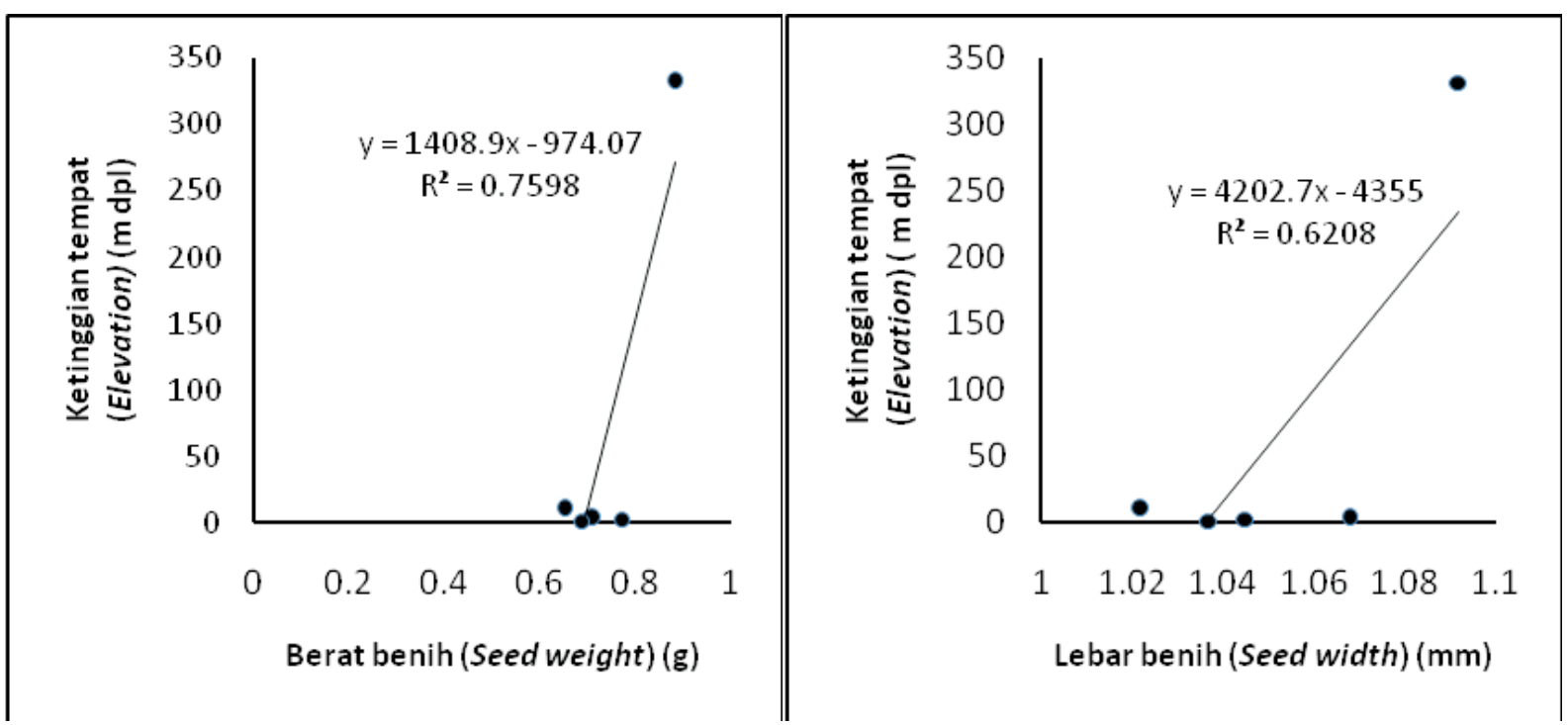

Gambar(Figure) 1. Hubungan ketinggian tempat dengan berat benih (kiri) dan lebar benih (kanan) (Correlation between elevation and seed weight (left), and width (right))

(Pluess et al., 2005). Variasi morfologi dan berat benih selain dipengaruhi oleh faktor lingkungan juga dikontrol oleh faktor genetik (Mkonda et al., 2003), dimana pada jenis dengan keragaman genetik yang rendah kemungkinan sedikit sekali perbedaan karakter morfologi antar kelompok benih tersebut.

Variasi sifat morfologi benih antar asal benih atau provenans secara singnifikan ditemukan juga pada benih Trigonobalanus doichangesis di Cina Selatan (Zeng et al., 2009) dan Celtis australis di Himalaya Tengah, India (Singh et al., 2006). Perbedaan morfologi antar kelompok benih dari 5 lokasi berbeda disebabkan perbedaan lingkungan tempat tumbuh yang berinteraksi dengan sel-sel genotip (Fenner, 1992 dalam Laurisen, 1999). Kelompok benih Alas Purwo mempunyai perbedaan morfologi yang cukup signifikan dengan kelompok lainnya seperti pada parameter tebal kulit benih dan panjang benih. Hal ini diduga karena kelompok benih Alas Purwo berasal dari populasi alami yang secara genetik lebih terisolir dibandingkan dengan populasi lainnya yang merupakan hutan tanaman yang mempunyai kemungkinan berasal dari sumber yang sama atau mempunyai hubungan kekerabatan yang dekat.

\section{B. Respon Kelompok Benih terhadap Beberapa Perlakuan Pra Perkecambahan}

Analisis ragam pengaruh perlakuan terhadap perkecambahan benih berpengaruh sangat nyata pada kelompok benih Mokmer, Benoa, Alas Purwo, dan Kaliurang, sedangkan untuk kelompok benih Lembar, perlakuan pra perkecambahan tidak berpengaruh nyata terhadap daya berkecambahnya. Untuk kecepatan berkecambah, perlakuan pra perkecambahan memberikan pengaruh sangat nyata pada semua kelompok benih (Lampiran 2).

Kelima kelompok benih sawo kecik memberikan respon yang bervariasi terhadap perlakuan pra perkecambahan (Tabel 4). Pada kelompok benih Lembar perlakuan pra perkecambahan tidak memberikan perbedaan nyata terhadap daya berkecambah benih, sedangkan untuk kecepatan berkecambah berbeda nyata, benih yang direndam air dingin selama 3 x 24 jam (A2) memberikan hasil terbaik. Untuk kelompok benih Mokmer dan Benoa, perlakuan rendam jemur selama 3 hari (A3) memberikan daya dan kecepatan berkecambah terbaik. Pada kelompok benih Alas Purwo perlakuan rendam jemur selama 3 hari (A3) dan direndam $\mathrm{KNO}_{3} \quad 0,2 \%$ selama 24 jam (A5) memberikan hasil terbaik terhadap daya dan kecepatan berkecambah benih, sedangkan untuk kelompok benih Kaliurang, perlakuan rendamjemur selama 3 x 24 jam (A3) dan benih direndam air dingin selama $3 \times 24$ jam (A2) memberikan daya dan kecepatan berkecambah tertinggi. 
Tabel(Table) 4. Daya berkecambah dan kecepatan berkecambah 5 seedlot pada beberapa perlakuan pra perkecambahan (Germination capacity and speed of 5 seedlots on the several pre treatment)

\begin{tabular}{|l|c|c|c|c|c|c|}
\hline \multirow{2}{*}{$\begin{array}{c}\text { Parameter } \\
\text { (Parame ters) }\end{array}$} & $\begin{array}{c}\text { Perlakuan } \\
(\text { Treatments })\end{array}$ & \multicolumn{5}{|c|}{ Kelompok benih (Seed lots) } \\
\cline { 2 - 7 } $\begin{array}{l}\text { Daya } \\
\text { berkecambah } \\
\text { (Germination } \\
\text { capacity) }\end{array}$ & $\mathrm{A} 0$ & $27 \mathrm{~b}$ & $50 \mathrm{~b}$ & $82 \mathrm{a}$ & $17 \mathrm{bc}$ & $77 \mathrm{~b}$ \\
\cline { 2 - 7 } & $\mathrm{A} 1$ & $23 \mathrm{~b}$ & $46 \mathrm{bc}$ & $82 \mathrm{a}$ & $5 \mathrm{~d}$ & $87 \mathrm{a}$ \\
\cline { 2 - 7 } & $\mathrm{A} 2$ & $7 \mathrm{c}$ & $10 \mathrm{~d}$ & $65 \mathrm{a}$ & $12 \mathrm{c}$ & $31 \mathrm{~d}$ \\
\cline { 2 - 7 } & $\mathrm{A} 3$ & $64 \mathrm{a}$ & $65 \mathrm{a}$ & $85 \mathrm{a}$ & $33 \mathrm{a}$ & $88 \mathrm{a}$ \\
\cline { 2 - 7 } & $\mathrm{A} 4$ & $22 \mathrm{~b}$ & $46 \mathrm{bc}$ & $69 \mathrm{a}$ & $19 \mathrm{~b}$ & $65 \mathrm{c}$ \\
\cline { 2 - 7 } & $\mathrm{A} 5$ & $20 \mathrm{~b}$ & $42 \mathrm{c}$ & $74 \mathrm{a}$ & $35 \mathrm{a}$ & $77 \mathrm{~b}$ \\
\hline $\begin{array}{l}\text { Kecepatan } \\
\text { berkecambah } \\
\text { (Germination } \\
\text { speed) }(\% / \mathrm{etmal})\end{array}$ & $\mathrm{A} 0$ & $0,5071 \mathrm{~b}$ & $1,2187 \mathrm{ab}$ & $2,0734 \mathrm{~b}$ & $0,4185 \mathrm{~b}$ & $1,8057 \mathrm{~b}$ \\
\cline { 2 - 7 } & $\mathrm{A} 1$ & $0,5390 \mathrm{~b}$ & $1,1325 \mathrm{ab}$ & $3,3032 \mathrm{a}$ & $0,1231 \mathrm{~d}$ & $2,3840 \mathrm{a}$ \\
\cline { 2 - 7 } & $\mathrm{A} 2$ & $0,1695 \mathrm{c}$ & $0,2462 \mathrm{c}$ & $1,7190 \mathrm{c}$ & $0,2954 \mathrm{c}$ & $0,7662 \mathrm{c}$ \\
\cline { 2 - 7 } & $\mathrm{A} 3$ & $1,9700 \mathrm{a}$ & $1,6003 \mathrm{a}$ & $1,6057 \mathrm{c}$ & $0,8125 \mathrm{a}$ & $2,3930 \mathrm{a}$ \\
\cline { 2 - 7 } & $\mathrm{A} 4$ & $0,4457 \mathrm{~b}$ & $1,1202 \mathrm{ab}$ & $1,4929 \mathrm{c}$ & $0,4678 \mathrm{~b}$ & $1,7116 \mathrm{~b}$ \\
\cline { 2 - 7 } & $\mathrm{A} 5$ & $0,4666 \mathrm{~b}$ & $1,0217 \mathrm{~b}$ & $1,4181 \mathrm{c}$ & $0,8617 \mathrm{a}$ & $2,0778 \mathrm{ab}$ \\
\hline
\end{tabular}

Keterangan(Notes): Angka rata-rata dalam kolom sama yang diikuti oleh huruf sama menunjukkan bahwa nilai rata-rata tidak berbeda nyata pada tingkat kepercayaan $95 \%$ uji Duncan (Means within a column followed by the same letters showed that mean are not significantly different at $95 \%$ confident level of Duncan's multiple range test). $A 0=$ t anpa perlakuan (control), $A 1=$ direndam air dingin selama $3 \times 24$ jam (soaking in the water for 3 days), A2 = direndam air panas dan dibiarkan dingin selama 24 jam (soaking in the hot water and cooling for 24 hours), $\mathrm{A} 3$ = direndam-jemur 3 hari (drying-soaking for 3 days), $\mathrm{A} 4=$ direndam $\mathrm{H}_{2} \mathrm{SO}_{4} 2 \mathrm{~N}$ selama 30 menit (soaking in $\mathrm{H}_{2} \mathrm{SO}_{4} 2 \mathrm{~N}$ for 2 hours), dan $\mathrm{A} 5=$ direndam $\mathrm{KNO}_{3} 0,2 \%$ selama 24 jam (soaking in $\mathrm{KNO}_{3}$ $0.2 \%$ for 24 hours).

Tabel(Table) 5. Koefisien korelasi Pearson antar daya dan kecepatan berkecambah benih dengan karakteristik morfologi, curah hujan dan ketinggian tempat (Pearson correlation coeffisients between seed germination capacity and speed with morphological traits, annual precipitation and elevation)

\begin{tabular}{|l|c|c|c|c|c|c|c|}
\hline \multicolumn{1}{|c|}{ Parameter (Parameters) } & PB & LB & TB & TKB & BB & CH & KT \\
\hline $\begin{array}{l}\text { Daya berkecambah } \\
\text { (Germination capacity) }(\%)\end{array}$ & $0,269^{\mathrm{ns}}$ & $\begin{array}{c}0,724 \\
\mathrm{~ns}\end{array}$ & $\begin{array}{c}-0,063 \\
\mathrm{~ns}\end{array}$ & $\begin{array}{c}-0,856 \\
*\end{array}$ & $0,556^{\mathrm{ns}}$ & $0,555^{\mathrm{ns}}$ & $0,555^{\mathrm{ns}}$ \\
\hline $\begin{array}{l}\text { Kecepatan berkecambah } \\
\text { (Germination speed) }(\% / \text { etmal) }\end{array}$ & $0,573^{\mathrm{ns}}$ & $\begin{array}{c}0,631 \\
\mathrm{~ns}\end{array}$ & $\begin{array}{c}-0,123 \\
\mathrm{~ns}\end{array}$ & $\begin{array}{c}-0,829 \\
*\end{array}$ & $0,783 *$ & $0,802 *$ & $0,690^{\mathrm{ns}}$ \\
\hline
\end{tabular}

Keterangan (Notes): $\mathrm{BB}=$ berat benih (seed weight), $\mathrm{PB}=$ panjang benih (seed length), $\mathrm{LB}=$ lebar benih (seed width), $\mathrm{TB}=\mathrm{tebal}$ benih (seed thickness), TKB=tebal kulit benih (seed coat thickness),

$*$ = Nyata pada tingkat kepercayaan 95\% (Significant at 95\% confident level) ns $=$ Tidak berpengaruh nyata $($ Not significant $)$

Kelompok benih Alas Purwo, Benoa, dan Mokmer memiliki daya berkecambah yang relatif masih rendah $(<80 \%)$ yang diduga disebabkan belum optimalnya perlakuan pendahuluan untuk ketiga kelompok benih tersebut. Secara keseluruhan perlakuan A3 memberikan hasil yang relatif lebih baik pada semua kelompok benih yang diuji.

Variasi respon perkecambahan kelima kelompok benih tersebut pada beberapa perlakuan pendahuluan menunjukkan adanya variasi dormansi benih antar populasi (asal benih). Benih yang berasal dari Lembar memiliki dormansi yang sangat rendah sehingga antar kontrol dengan perlakuan lainnya relatif tidak berbeda nyata, sedangkan benih yang berasal dari Alas Purwo mempunyai dormansi paling kuat. Diduga kulit benih yang tebal menghambat proses perkecambahan benih asal Alas Purwo (Tabel 2). Hasil uji korelasi antar daya dan 
kecepatan berkecambah dengan karakteristik morfologi, curah hujan, dan ketinggian tempat menunjukkan bahwa tebal kulit benih berkorelasi dengan daya dan kecepatan berkecambah $(\mathrm{r}=$ $0,856, r=-0,829)$ (Tabel 5). Benih dengan kulit yang lebih tebal mempunyai kecenderungan daya dan kecepatan berkecambahnya makin rendah (Gambar 2). Korelasi lainnya yang sifatnya positif terjadi antara curah hujan dengan kecepatan berkecambah $(r=0,802)$. Benih yang diunduh dari daerah dengan curah hujan lebih tinggi relatif lebih cepat berkecambah yang ditunjukkan dengan kecepatan berkecambah lebih tinggi (Gambar 3).

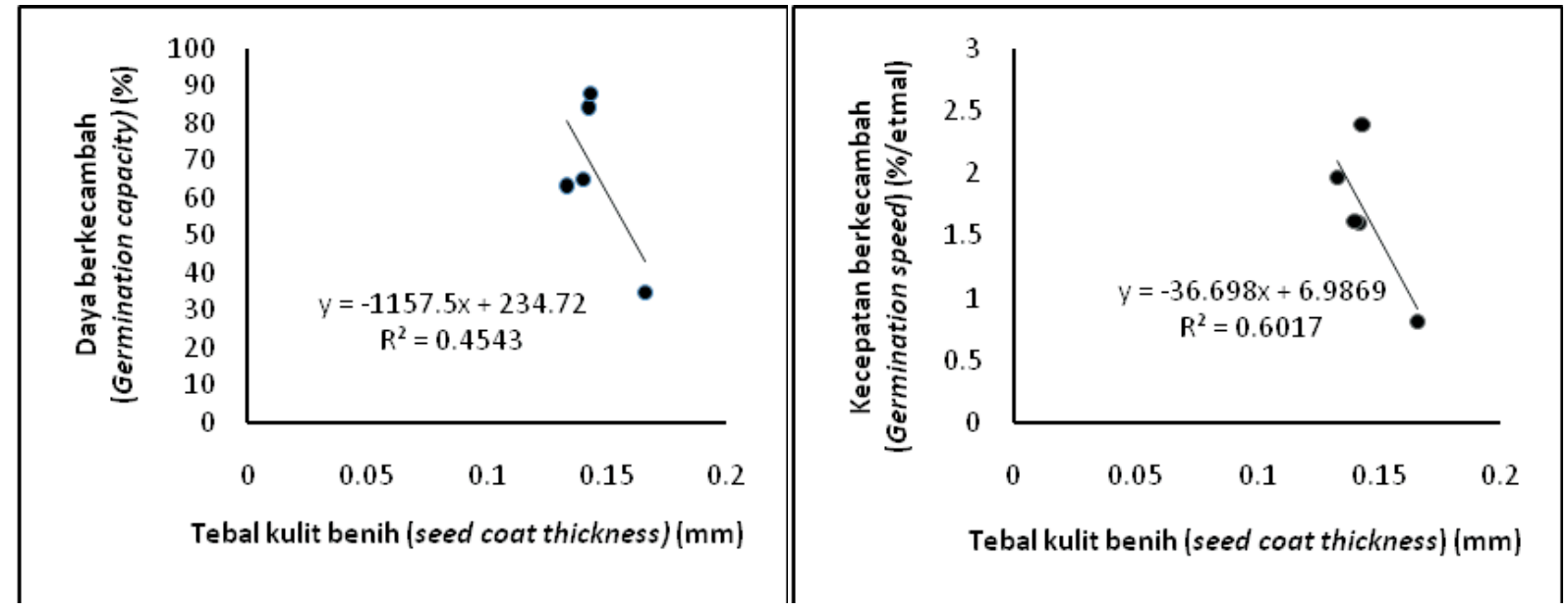

Gambar(Figure) 2. Hubungan antar tebal kulit benih dengan daya berkecambah dan kecepatan berkecambah (Correlation between seed coat thickness and germination capacity and speed)
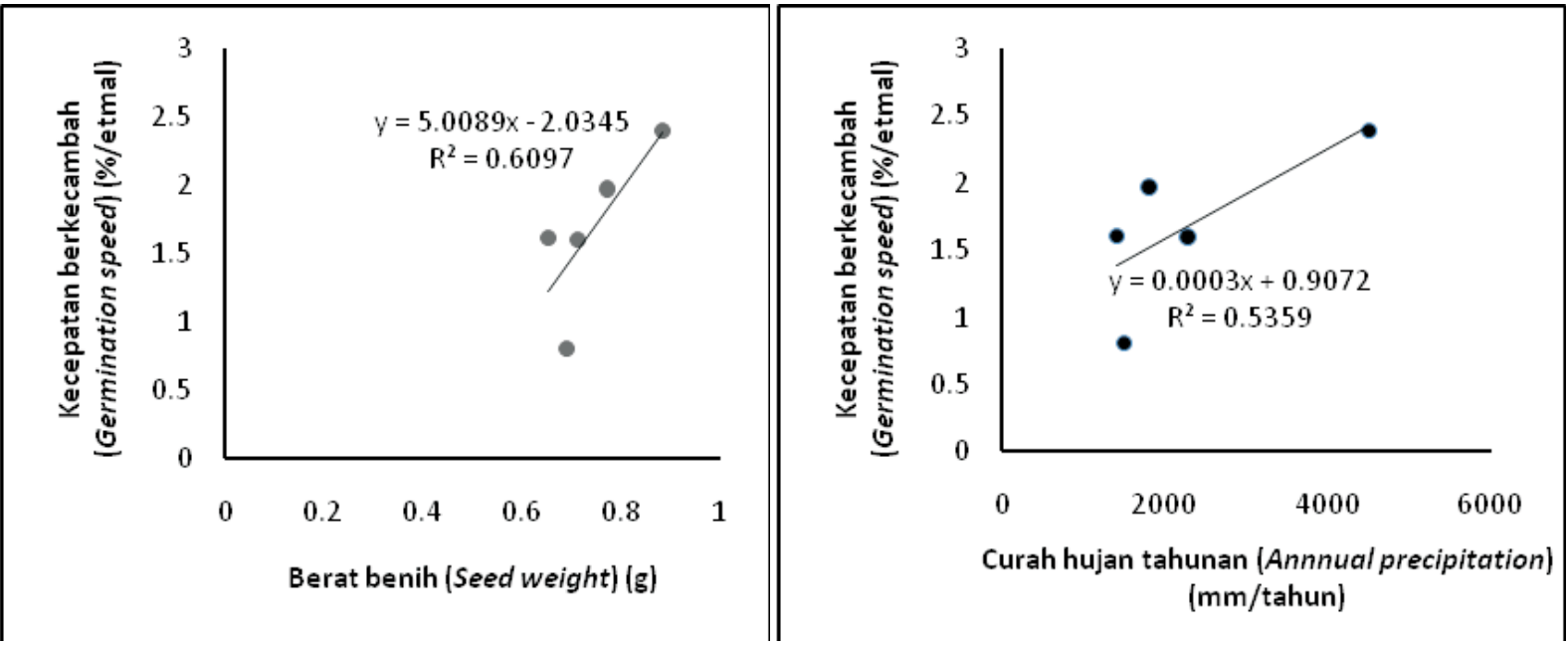

Gambar(Figure) 3. Hubungan berat benih dan curah hujan tahunan dengan kecepatan berkecambah (Correlation between seed weight and annual precipitation, and germination speed)

Perkecambahan benih dipengaruhi oleh berbagai faktor seperti mutu benih, perlakuan awal (pematahan dormansi), dan kondisi perkecambahan (air, suhu, media, cahaya) (Schmidt, 2002). Efektivitas perlakuan pendahuluan pada suatu jenis tergantung dari intensitas dormansi masing-masing kelompok benih karena intensitas dormansi dapat bervariasi antar kelompok benih. Menurut Khurana dan Singh (2001), dormansi benih berhubungan dengan karakteristik lingkungan seperti kecenderungan musim hujan dan periode musim kemarau tahunan. 


\section{KESIMPULAN}

1. Asal benih berpengaruh nyata terhadap morfologi benih. Kelompok benih yang berasal dari Kaliurang dan Benoa mempunyai panjang dan berat benih yang lebih tinggi, namun kelompok benih Kaliurang mempunyai ukuran yang lebih besar jika dilihat dari lebar benih. Untuk tebal kulit benih, kelompok benih Alas Purwo mempunyai kulit benih yang lebih tebal.

2. Perlakuan pendahuluan sangat berpengaruh nyata terhadap kelompok benih Mokmer, Alas Purwo, Kaliurang, dan Benoa, sedangkan untuk kelompok benih Lembar, perlakuan pendahuluan tidak berpengaruh nyata terhadap daya berkecambahnya. Benih asal Alas Purwo mempunyai daya dan kecepatan berkecambah yang paling rendah yang disebabkan oleh tebalnya kulit benih. Semua perlakuan pendahuluan pada kelompok benih Alas Purwo, Mokmer, dan Benoa tidak mampu mematahkan dormansi benih secara optimal yang ditunjukkan oleh masih rendahnya daya berkecambah $(<80 \%)$ pada masing-masing kelompok benih tersebut. Untuk kelompok benih Kaliurang perlakuan rendah jemur 3 hari (A3) dan perendam benih dalam air panas dan dibiarkan dingin selama 24 jam (A1) memberikan daya dan kecepatan berkecambahan tertinggi. Namun secara umum, perlakuan A3 memberikan hasil perkecambahan lebih baik pada 5 kelopok benih yang diuji.

3. Ketinggian tempat tumbuh berkorelasi positif dengan berat dan lebar benih $(\mathrm{r}=$ $0,877$ dan $r=0,807)$. Tebal kulit benih berkorelasi negatif dengan daya dan kecepatan berkecambah $(\mathrm{r}=-0,856 ; \mathrm{r}=$ 0,829 ). Benih yang memiliki kulit benih lebih tebal mempunyai daya dan kecepatan berkecambah lebih rendah. Korelasi lainnya yang sifatnya positif terjadi antara curah hujan dengan kecepatan berkecambah $(\mathrm{r}=$ 0,802 ).

\section{DAFTAR PUSTAKA}

Alrasyid, H. 1971. Keterangan tentang Silvikultur Sawo Kecik (Manilkara kauki
Durbard, Sapotaceae). Laporan No. 127. Lembaga Penelitian Hutan. Bogor.

Andersen, U.S., J.P.P. Cordova, U.B. Nielsen, and J. Kollmann. 2008. Provenance Variation in Germination and Seedling Growth of Abies guatemalensis Rehder. Forest Ecology and Management. 255(5):1831-1840.

Ayana, A. and E. Bekele. 2000. Geographical Patterns of Morphological Variation in Shorgum (Shorgum bicolor (L.) Moench) Germplasm from Ethiopia and Eritrea: Quantitative Characters. Euphytica 115: 91-104.

Bonner, F.T. 1987. Importance of Seed Size in Germination and Seedling Growth. Southern Forest Experiment Station. USDA. New Orleans, Louisiana.

Boulli, A., Baaziz, M., and O. M'Hirit. 2001. Polymorphism of Natural Population of Pinus halepensis Mill in Marocco as Revealed by Morphological Characters. Euphytica 119: 309-316.

Holm, S.O. 1994. Reproductive Pattern of Betula pendula and B. pubescens Coll. along a Regional Altitude Gradient in Northern Sweden. Ecography. 17:60-72.

Jayusman. 2006. Klasifikasi Kemenyan Berdasarkan Variabilitas Fenotifik di Tapanuli Utara. Jurnal Penelitian Hutan Tanaman. 3(1):233-245. Pusat Penelitian dan Pengembangan Hutan Tanaman. Bogor.

Khurana, E. And J. S. Singh. 2001. Ecology of Tree Seed and Seedlings: Implication for Tropical Forest Conservation and Restoration. Current Science. 8(6):748757.

Kusumawardhani, E. 1997. Pengaruh Daerah Asal Sumber Benih dan Perlakuan Pematahan Dormansi terhadap Viabilitas Benih Kemiri (Aleurites moluccana Willd.). Jurusan Budidaya Pertanian, Fakultas Pertanian, Institut Pertanian Bogor. (Skripsi, tidak diterbitkan).

Laurisen, E. B. 1999. Pengaruh dari Kegiatan Penanganan Benih dan Persemaian terhadap Mutu Benih. Training Course on 
Basic Forest Genetics. Wanagama, Yogyakarta 3-7 Mei 1999. Kerjasama Indonesia Forest Seed Project dengan Universitas Gadjah Mada. Yogyakarta.

Loha, A., Tigabu, M., Teketay, D., Lundkvist, K. and A. Fries. 2006. Provenances Variation in Seed Morphometric Traits, Germination, and Seedling Growth of Cordia africana Lam. New Forests. 23: 19-30.

Mamo, N., M. Mihretu, M. Fakadu, M. Tigabu, and D. Teketay. 2006. Variation in Seed and Germination Characteristics among Juniperus procera population in Ethiopia. Forest Ecology and Management, 225: $320-327$.

Mkonda, A., Lungu, S., Maghembe, J.A., and P.L. Mafongoya. 2003. Fruit and Seed Germination Characters of Stychonos cocculoides. An Indigenous Fruit Tree from Natural Population in Zambia. Agroforestry System. 58:25-31.

Pluess, A.R., Schutz, W., and J. Stocklin. 2005. Seed Weight Increases with Altitude in the Swiss Alps between Related Species but not among Population of Individu Species. Oecologia 144:55-61.
Schmidt, L. 2000. Pedoman Penanganan Benih Tanaman Hutan Tropis dan Subtropis. Terjemahan. Kerjasama Direktorat Jenderal Rehabilitasi Lahan dan Perhutanan Sosial dengan Indonesia Forest Seed Project. PT. Gramedia Jakarta.

Singh, B., B.P. Bhatt and P. Prasad. 2006. Variation in Seed and Seedling Traits of Celtis australis, a Multipurpose Tree, in Central Himalaya, India. Agroforestry Systems 67:115-122.

Steel, R.G.D., and J.H. Torrie. 1980. Principles and Procedures of Statistic. McGraw-Hill, Inc.

Totland, O. and H.J.B. Birks. 1996. Factor Influencing Inter-population Variation in Ranunculus acris Seed Production in Aphine Area of Southwestern Norway. Ecography. 19:269-278.

Zheng, Y.I., W.B. Sun, Y. Zhou, and D. Coombs. 2009. Variation in Seed and Seedling Traits among Natural Populations of Trigonobalanus doichangesis (A. Camus) Forman (Fagaceae), a Rare and Endangered Plant in Southwest China. New Forests 37: 285-294.. 
Lampiran (Appendix) 1. Hasil uji F pengaruh populasi terhadap panjang, lebar benih, tebal benih, tebal kulit dan berat per butir benih sawo kecik (Result of F-test of the effect of population on seed length, seed width, seed thickness, seed coat thickness, and seed weight of sawo kecik)

\begin{tabular}{|c|l|c|}
\hline No. & Parameter (Parameters) & F-hitung $($ F-calc.) \\
\hline 1. & Panjang benih (seed length) & $23,777 * *$ \\
2. & Leba r benih (seed width) & $5,052 * *$ \\
3. & Tebal benih (seed thickness) & $4,790 * *$ \\
4. & Tebal kulit benih (seed coat thickness) & $4,846 * *$ \\
5. & Berat benih (seed weight) & $55,440 * *$ \\
\hline
\end{tabular}

Keterangan (Notes):**=Berpengaruh nyata pada tingkat kepercayaan 99\% (Significant at 99\% confident level)

Lampiran (Appendix) 1. Hasil uji F pengaruh perlakuan pra perkecambahan terhadap daya dan kecepatan berkecambah pada 5 kelompok benih sawo kecik (Result of $F$-test of germination pre treatment on germination capacity and speed offive sawo kecik seed lots)

\begin{tabular}{|l|l|c|c|c|c|c|}
\hline No. & $\begin{array}{l}\text { Parameter } \\
\text { (parameters) }\end{array}$ & Lembar & Mokmer & Benoa & Alas Purwo & Kaliurang \\
\cline { 2 - 6 } & $\begin{array}{l}\text { Daya berkecambah } \\
\text { (germination } \\
\text { capacity) }\end{array}$ & $1,739 \mathrm{~ns}$ & $24,163^{* *}$ & $23,362^{* *}$ & $22,470^{* *}$ & $15,688^{* *}$ \\
\hline 2. & $\begin{array}{l}\text { Kecepatan } \\
\text { berkecambah } \\
\text { (germination speed })\end{array}$ & $13,705^{* *}$ & $24,165^{* *}$ & $30,653^{* *}$ & $22,040^{* *}$ & $13,056^{* *}$ \\
\hline
\end{tabular}

Keterangan (Notes): ** = Berpengaruh nyata pada tingkat kepercayaan 99\% (Significant at 99\% confidence level) ns $=$ Tidak berpengaruh nyata $($ Not significant $)$ 